\title{
Agricultural burning smoke in eastern Washington-part I: Atmospheric characterization
}

\author{
Jorge Jimenez $^{\mathrm{a}, *}$, Chang-Fu Wu ${ }^{\mathrm{b}}$, Candis Claiborn ${ }^{\mathrm{a}}$, Tim Gould ${ }^{\mathrm{d}}$, \\ Christopher D. Simpson ${ }^{c}$, Tim Larsond, L.-J. Sally Liu ${ }^{\mathrm{c}, \mathrm{e}}$ \\ ${ }^{a}$ Department of Civil and Environmental Engineering, Washington State University, Pullman, WA 99164, USA \\ ${ }^{\mathrm{b}}$ Department of Public Health, National Taiwan University, Taipei 100, Taiwan \\ ${ }^{c}$ Department of Environmental and Occupational Health Sciences, University of Washington, Seattle, WA 98195, USA \\ ${ }^{\mathrm{d}}$ Department of Civil and Environmental Engineering, University of Washington, Seattle, WA 98195, USA \\ ${ }^{\mathrm{e}}$ Institute of Social and Preventive Medicine, University of Basel, Switzerland
}

Received 1 April 2005; accepted 14 September 2005

\begin{abstract}
Agricultural burning has been subject to intense debate in Eastern Washington. Rural communities are concerned about health impacts related to smoke exposure from field burning. However, the short-duration excursions of smoke often do not violate air quality standards at locations where air quality monitors are situated. The purpose of this study was to characterize the air quality in Pullman, WA during the fall 2002 prescribed field burning season, as part of a larger study conducted to examine community exposure to agricultural burning smoke and the related short-term health effects. Data collected included continuous $\mathrm{PM}_{2.5}, \mathrm{PM}_{10}, \mathrm{CO}_{2}$, nitrogen oxides, and 12-h integrated $\mathrm{PM}_{2.5}, \mathrm{OC}$, EC, and levoglucosan (a biomass burning marker). Four episodes were defined when three consecutive 30 -min $\mathrm{PM}_{2.5}$ averages exceeded $40 \mu \mathrm{g} \mathrm{m}^{-3}$. Two source-receptor models; the chemical mass balance model (CMB) and positive matrix factorization (PMF) were used to estimate smoke intrusion from regional agricultural burning. During this study, the average $\mathrm{PM}_{2.5}, \mathrm{OC}_{\text {, and }}$ EC were similar during the daytime and nighttime, while LG was twice as high during the night. The CMB results showed major contributions of $\mathrm{PM}_{2.5}$ from soil (38\%), vegetative burning (35\%), and sulfate aerosol (20\%), and much less from vehicles $(2 \%)$ and cooking (1\%). The 3-source profiles generated by PMF were consistent with those selected for CMB modeling. The $\mathrm{PM}_{2.5}$ estimates from these two models were highly correlated for individual sources. The $\mathrm{LG}, \mathrm{NO}_{x}, \mathrm{CO}_{2}$, $\mathrm{OC}$, and apportioned $\mathrm{PM}_{2.5}$ from vegetative burning and soil were higher during the episodes than during non-episode days, while EC and $\mathrm{PM}_{2.5}$ from secondary sulfate, vehicles, and cooking sources were similar throughout the study. We characterized the episodes of agricultural field burning with elevated LG, OC, and biomass burning contribution to $\mathrm{PM}_{2.5}$. (C) 2005 Elsevier Ltd. All rights reserved.
\end{abstract}

Keywords: Biomass burning; Smoke impact in rural communities; Source apportionment; Exposure assessment; Receptor model

*Corresponding author.

E-mail address: jimenez@mail.wsu.edu (J. Jimenez).

\section{Introduction}

In the past decade, agricultural burning has been subject to intense discussion and public debate in the semi-arid Eastern Washington (Jimenez, 2002). 
Neighboring communities from rural areas have noticed an impact on air quality from farmers' burning practices, and citizens have voiced health concerns related to smoke exposure, as well as potentially negative impacts on tourism and economic activities (Roberts and Corkill, 1998). Smoke from biomass burning contains numerous chemical compounds including, but not limited to, carbon monoxide (CO), $\mathrm{NO}_{2}$, volatile organic compounds (Jenkins et al., 1996), and particulate matter with an aerodynamic diameter less than $2.5 \mu \mathrm{m}\left(\mathrm{PM}_{2.5}\right)$. In Eastern Washington, other than agricultural field burning, there are several important sources of $\mathrm{PM}_{2.5}$ including regional forest fires and fugitive dust from roads and occasional wind blown dust (Claiborn et al., 2000; Kim et al., 2003). Fugitive dust in this region contains significant portion of geological material, and overlaps the $\mathrm{PM}_{2.5}$ at aerodynamic diameters between 1 and $3 \mu \mathrm{m}$ (Claiborn et al., 2000).

$\mathrm{PM}_{2.5}$ in biomass burning smoke can have a potentially detrimental impact on human health from both acute and chronic exposures (US EPA, 2004). Chronic exposure to biomass smoke could reduce lung function, depress the immune system and increase the risk of respiratory diseases (Sutherland, 2004; Sutherland and Martin, 2003). There is evidence that short-term excursions in $\mathrm{PM}_{2.5}$ result in acute health effects on susceptible people including COPD, cardiovascular patients, and asthmatic children (Romieu et al., 1996; Pekkanen et al., 1997; Peters et al., 1997; Vedal et al., 1998; Roemer et al., 2000; Yu et al., 2000; Ostro et al., 2001; Delfino et al., 2002, 2003). The health effects include cough, wheezing, chest tightness, and shortness of breath. Long et al. (1998) reported from their questionnaire-based survey in Winnipeg, Canada that individuals with asthma or chronic bronchitis were more likely to be affected by straw burning. Tirigoe et al. (2000) also found a relationship between $\mathrm{PM}_{10}$ and children with asthma attacks, with the rise of $\mathrm{PM}_{10}$ most likely from rice straw burning in Niigata, Japan. However, short-term $\mathrm{PM}_{2.5}$ excursions are not currently regulated.

Agricultural burning in eastern Washington occurs primarily in the spring and fall, involving burning of mainly residues of cereal grain including wheat and barley. Approximately 2000 agricultural fires are set each year in Washington State (WDOE, 2004) over an area of $\sim 15,000 \mathrm{~km}^{2}$, with a total population of $\sim 160,000$ (WDOE, 2004). However, only six monitoring sites report real-time $\mathrm{PM}_{2.5}$ concentrations in this area. This small number of monitoring sites likely result in an inadequate monitoring of smoke episodes under varying meteorological conditions. Evidence was provided by the disagreement between the $\mathrm{PM}_{2.5}$ measurements and the amount of land burned or the number of smoke related complaints (Jimenez, 2002). Since the NAAQS for $\mathrm{PM}_{10}$ and $\mathrm{PM}_{2.5}$ are based on 24-h or annual average concentrations, these smoke episodes do not necessarily violate the NAAQS due to their relatively short duration and the scarcity of the monitors in Eastern Washington. Thus few studies have been conducted to characterize air quality during $\mathrm{Ag}$ burning episodes and even less about the associated health effects.

The purpose of this study was to characterize air quality during a period of prescribed agricultural field burning in an eastern Washington town, as part of a larger study examining community exposure to agricultural burning smoke and the related health effects. As part of this work, two source-receptor models were used to estimate the impacts of smoke intrusion from regional agricultural field burning on the observed $\mathrm{PM}_{2.5}$ mass concentrations in Pullman.

\section{Methods}

\subsection{Monitoring period and site selection}

This study was conducted in the 2002 fall $\mathrm{Ag}$ burning season (September-November) based on the historical evidence for greater amounts of acres burned per day and more smoke episodes reported by citizens in the fall burning season (Jimenez, 2002). The air quality measurements analyzed in this paper were collected primarily at one central monitoring site located on the roof of a building at Washington State University (WSU) in Pullman, WA (elevation $=770 \mathrm{~m}$, approximately $12 \mathrm{~m}$ above street level). Measurements from this site were used to represent the ambient exposure of subjects on the WSU campus (average elevation $=768 \mathrm{~m}$ ) and in the general Pullman area (average elevation $=$ $774 \mathrm{~m}$ ). In addition, we used this data, along with measurements collected inside the study subjects' residences and time-location-activity information to estimate personal exposures to $\mathrm{PM}_{2.5}$ from outdoor sources and from agriculture burning smoke using a random component superposition model, a recursive mass balance model, and a total exposure 
model. This analysis is reported elsewhere (Wu et al., 2005). The distance from the monitoring site to the burning fields depended on the location of the field relative to the monitoring site, which ranged from a few to $200 \mathrm{~km}$.

\subsection{Air quality sampling}

PM measurements were taken from a continuous $\mathrm{PM}_{10}$ and $\mathrm{PM}_{2.5}$ tapered element oscillating microbalance (TEOM) monitors (30-min averages. Series 1400a, Thermo Electron Co), a light scattering nephelometer (10-min averages. M903, Radiance Research, Seattle, WA), and a DataRAM with a $\mathrm{PM}_{2.5}$ size-selective inlet (10-min averages, ThermoAndersen, Smyrna, GA). In addition, 12-h integrated $\mathrm{PM}_{2.5}$ samples (operated from 0800 to 2000 and from 2000 to 0800 , PST) were taken from collocated and triplicate single-stage 10-LPM Harvard Impactors $\left(\mathrm{HI}_{2.5}\right.$ ) (Air Diagnostics Inc., Naples, ME). Two $\mathrm{HI}_{2.5}$ sampled $\mathrm{PM}_{2.5}$ onto $37-\mathrm{mm}$ Teflon filters, and the third sampled onto a quartz filter. The nephelometer was calibrated against the $\mathrm{HI}_{2.5}$ measurements (intercept $=0.134 \times 10^{-5} \mathrm{~m}^{-1}$, slope $\left.=0.243 \times 10^{-5} \mathrm{~m}^{2} \mu \mathrm{g}^{-1}, R^{2}=0.83, N=99\right)$. Other air constituents included continuous carbon dioxide (10-min average, Telaire 1050 Engelhard, Goleta, CA), nitrogen oxides (10-min average, model 42 Thermal Environmental Instruments, Inc.), and carbon monoxide (10-min average, Model 9830 Monitor Labs, Inc.). Meteorological parameters including temperature, humidity, wind speed and wind direction were also recorded using a small weather station (30-min average, WeatherLink, Davis Instruments Corp. Hayward, CA 94545).

The PM collected on the Teflon media was analyzed gravimetrically using a Mettler-Toledo UMT2 microbalance at the University of Washington laboratory, at constant temperature (22.2 $\left.\pm 1.8^{\circ} \mathrm{C}\right)$ and relative humidity $(34.8 \pm 2.5 \%)$ for at least $24 \mathrm{~h}$ prior to weighing (Allen et al., 2001). Filters were then analyzed for 55 inorganic elements using X-ray fluorescence (XRF) at Chester LabNet, Tigard, Oregon. One set of the duplicate Teflon filters was extracted by ultrasonication in ethylacetate/triethylamine for LG analysis using gas chromatography-mass spectrometry (GC-MS) (Simpson et al., 2004). Sections of the quartz filters $\left(1 \mathrm{~cm}^{2}\right)$ were analyzed for OC and EC via Thermal Optical Transmittance (Sunset Laboratory, Inc. Tigard, OR) using a modified version of the NIOSH 5040 method (Pang et al., 2002).

\subsection{Episode definition}

An episode was declared when three or more 30min average $\mathrm{PM}_{2.5}$ concentrations exceeded $40 \mu \mathrm{g} \mathrm{m}^{-3}$ during any 24 -h period according to the central site $\mathrm{PM}_{2.5}$ TEOM and/or DataRAM measurements. This threshold value was selected based on the frequency of historical (2000 and 2001) hourly nephelometer $\mathrm{PM}_{2.5}$ readings exceeding this magnitude at the downtown Pullman air quality monitoring site operated by the Washington State Department of Ecology (WDOE) (see Table 1). Our previous study (Jimenez, 2002) also found a link between these exceedances and vegetative burning smoke episodes in Pullman. Episode declamation was aided by visual observations of agricultural burning smoke plumes that were not upwind of the central site monitors; current and predicted meteorological conditions that may favor the occurrence of an episode; and the WDOE's daily morning burn calls for neighboring regions. This study also included a single-sided blind sham episode (not a smoke episode) declared during a period of relatively low $\mathrm{PM}_{2.5}$ in order to compare the subject health effect responses with true episode periods. A declared episode triggered three consecutive days of intensive health effect monitoring (for more details on the exposure and health assessments, see $\mathrm{Wu}$ et al., 2005; Sullivan et al., 2005).

\subsection{Quality control}

Field blanks and duplicates were deployed so that they comprised at least $10 \%$ of the total $\mathrm{HI}_{2.5}$ sample size. The precision $\left(1.2 \mu \mathrm{g} \mathrm{m}^{-3}\right)$ and accuracy $(3 \%)$ of the $\mathrm{HI}_{2.5}$ have been reported in a previous paper (Liu et al., 2003). Filters were analyzed for LG in batches of approximately 20 filters. In each batch, two laboratory blanks and four spiked

Table 1

Historical $\mathrm{PM}_{2.5}$ hourly nephelometer measurements at the near downtown Pullman monitoring site operated by the Washington State Department of Ecology

\begin{tabular}{lccc}
\hline Range of $\mathrm{PM}_{2.5}$ & \multicolumn{3}{l}{ September-October } \\
\cline { 2 - 4 } & Year 2000 & Year 2001 & Year 2002 \\
& Frequency & Frequency & Frequency \\
\hline $0<\mathrm{PM}_{2.5}<10 \mu \mathrm{g} \mathrm{m}^{-3}$ & 1113 & 992 & 753 \\
$10<\mathrm{PM}_{2.5}<40 \mu \mathrm{g} \mathrm{m}^{-3}$ & 332 & 117 & 635 \\
$\mathrm{PM}_{2.5}>40 \mu \mathrm{g} \mathrm{m}^{-3}$ & 13 & 4 & 4 \\
\hline
\end{tabular}


samples (with $d^{7}$-levoglucosan in the extracts) were analyzed. The overall recovery based on the spiked samples was $75 \pm 11 \%$. The analytical precision based on $10-15 \%$ of samples analyzed in duplicate was $24 \%$. Among the 104 samples analyzed for LG, nine samples were below the limit of detection (LOD $1.4 \mathrm{ng} \mathrm{m}^{-3}$ ) and two samples had fatal analytical errors (unacceptably low recoveries, failure to derivatize, or chromatographic interferences).

\subsection{Data analysis}

The collected data for PM, gaseous pollutants, and particulate carbonaceous species at the central site were tested for normality and non-normally distributed data were conformed using the Box-Cox conformation (Box and Cox, 1964). Statistical differences between episode and non-episode periods in pollution levels were tested using a one-tailed two-sample $t$-test. Source apportioned $\mathrm{PM}_{2.5}$ mass concentrations (described below) were also compared between the episode and non-episode periods. Data used for source apportionment analysis were subjected to several constraints and consistency checks. $\mathrm{HI}_{2.5}$ measurements were compared to those from the $\mathrm{TEOM}_{2.5}$ and to the reconstructed fine mass (RCFM), which is defined as the sum of the individual components of fine PM fractions from each chemical analysis; i.e. OC, EC and inorganic elements (Malm et al., 1994)

$$
\begin{aligned}
\mathrm{RCFM}= & 1.6[\mathrm{OC}]+[\mathrm{EC}]+[\text { sulfate }]+[\text { nitrate }] \\
& +[\text { soil }]+[\text { others }],
\end{aligned}
$$

where the brackets denote mass concentrations $\left(\mu \mathrm{g} \mathrm{m}^{-3}\right)$ of each component. "Soil" corresponds to the sum of elements predominately associated with soil ( $\mathrm{Fe}, \mathrm{Al}, \mathrm{Si}, \mathrm{Ca}$, and $\mathrm{Ti}$ ), plus oxygen for the oxidized state of these elements $\left(\mathrm{AL}_{2} \mathrm{O}_{3}, \mathrm{SiO}, \mathrm{CaO}\right.$, $\mathrm{FeO}, \mathrm{Fe}_{2} \mathrm{O}_{3}, \mathrm{TiO}_{2}$ ).

$$
\begin{aligned}
\text { Soil }= & 2.20[\mathrm{Al}]+2.49[\mathrm{Si}]+1.63[\mathrm{Ca}]+2.42[\mathrm{Fe}] \\
& +1.94[\mathrm{Ti}] .
\end{aligned}
$$

"Others" represents all other elements that were analyzed. RCFM was calculated for all 12-h samples based on the XRF and EC/OC results and compared to the observed $\mathrm{HI}_{2.5}$ mass concentration.

For source apportionment, we used the US EPA's Chemical Mass Balance receptor model Version 8 (CMB) (Watson et al., 2001). The inputs to the CMB model were the $\mathrm{PM}_{2.5}$ chemical composition data, the mass fraction of the chemical species in the source profiles, and the uncertainties of individual species. Chemical species with large uncertainties have less influence in the solution because in the fitting procedure they are not weighed as much as those more precisely measured species or unique tracers. The sources of $\mathrm{PM}_{2.5}$ selected in the CMB model included airborne dust (soil), vegetative burning smoke, secondary sulfate aerosol, vehicular traffic, and cooking fumes. The soil and sulfate aerosol profiles were derived from the Spokane dust profile (Core, 1982) and a previous source apportionment study in Spokane (Kim et al., 2003). The vegetative burning smoke profile was derived from a previous source apportionment study in Spokane (Hoffman, 2002) and other documented studies of emission factors for wood smoke reporting LG (Oros and Simoneit, 2001a; Oros and Simoneit, 2001b). We also included profiles documented in the receptor model source composition library (US EPA-450/4-85-002) for vehicular traffic (Cass and McRae, 1981) and cooking fumes (Hildemann et al., 1991). The chemical tracers considered for modeling were $\mathrm{Al}, \mathrm{Br}, \mathrm{Ca}, \mathrm{Cl}, \mathrm{Cu}, \mathrm{OC}, \mathrm{EC}, \mathrm{Fe}, \mathrm{K}, \mathrm{Mn}, \mathrm{S}, \mathrm{Si}$, $\mathrm{SO}_{4}, \mathrm{Ti}, \mathrm{Zn}$ and LG. We excluded other elements with more than $70 \%$ samples below detection limit.

In addition to the CMB model, we also applied the positive matrix factorization model (PMF) for source apportionment. The PMF model is a statistical model that adopts a weighted leastsquares approach to solve the factor analysis problem and does not require prior knowledge of the source profiles (Paatero, 1997). We followed the procedure of Polissar et al. (2001) and Maykut et al. (2003) to generate the PMF model inputs and assign uncertainties to each measurement. We examined both a three-source (3S) and a four-source (4S) model, and tested various FPEAK parameters, ranging from -0.8 to 0.8 with increments of 0.1 (Paatero, 1997; Maykut et al., 2003). The ' $Q$ values' indicated that FPEAK values between -0.4 and 0.1 provided the optimum solutions for both models. After the source contribution factors were determined by PMF, they were re-scaled by regressing them against the corresponding $\mathrm{PM}_{2.5}$ mass concentrations to obtain both the source-specific $\mathrm{PM}_{2.5}$ mass contributions and mass fraction based source profiles. The 4-source PMF model identified one more source, "others," in addition to the three identified by the 3-source PMF model. However, the use of PMF in this study is limited by the small sample size $(N=123)$. When we forced the PMF to 
produce four sources, we artificially introduced errors. The 3-source PMF model results provided results that were more consistent with the $\mathrm{CMB}$ results than the 4-source PMF model, so the 4source model was not analyzed further.

\section{Results and discussion}

\subsection{Air quality measurements}

The TEOM 2.5, TEOM $_{10}$, and nephelometer data (September 2002-October 2002) are shown in Fig. 1. During several episodes, TEOM $_{2.5}$ measure- ments spiked above $40 \mu \mathrm{g} \mathrm{m}^{-3}$ and triggered two episode calls, including the periods of September 11-15 during which two consecutive episode calls were made, and October 17-19. Two episodes that were not declared occurred during September 25-26 and October 24-26. A sham episode was declared for October 9-11. The TEOM 2.5 was not functioning from $9 / 28$ to $10 / 17$, during which period the nephelometer data was used instead. Table 2 summarizes the measurements of $\mathrm{PM}$ and gaseous pollutants $\left(\mathrm{CO}_{2}, \mathrm{CO}\right.$ and $\left.\mathrm{NO}_{x}\right)$. The mean $\mathrm{PM}_{10}$ and $\mathrm{PM}_{2.5}$ levels were $40.5 \pm 38.8, \quad 13.6 \pm 9.4$ (TEOM), and $11.3 \pm 7.9 \mu \mathrm{g} \mathrm{m}^{-3}$ (nephelometer),
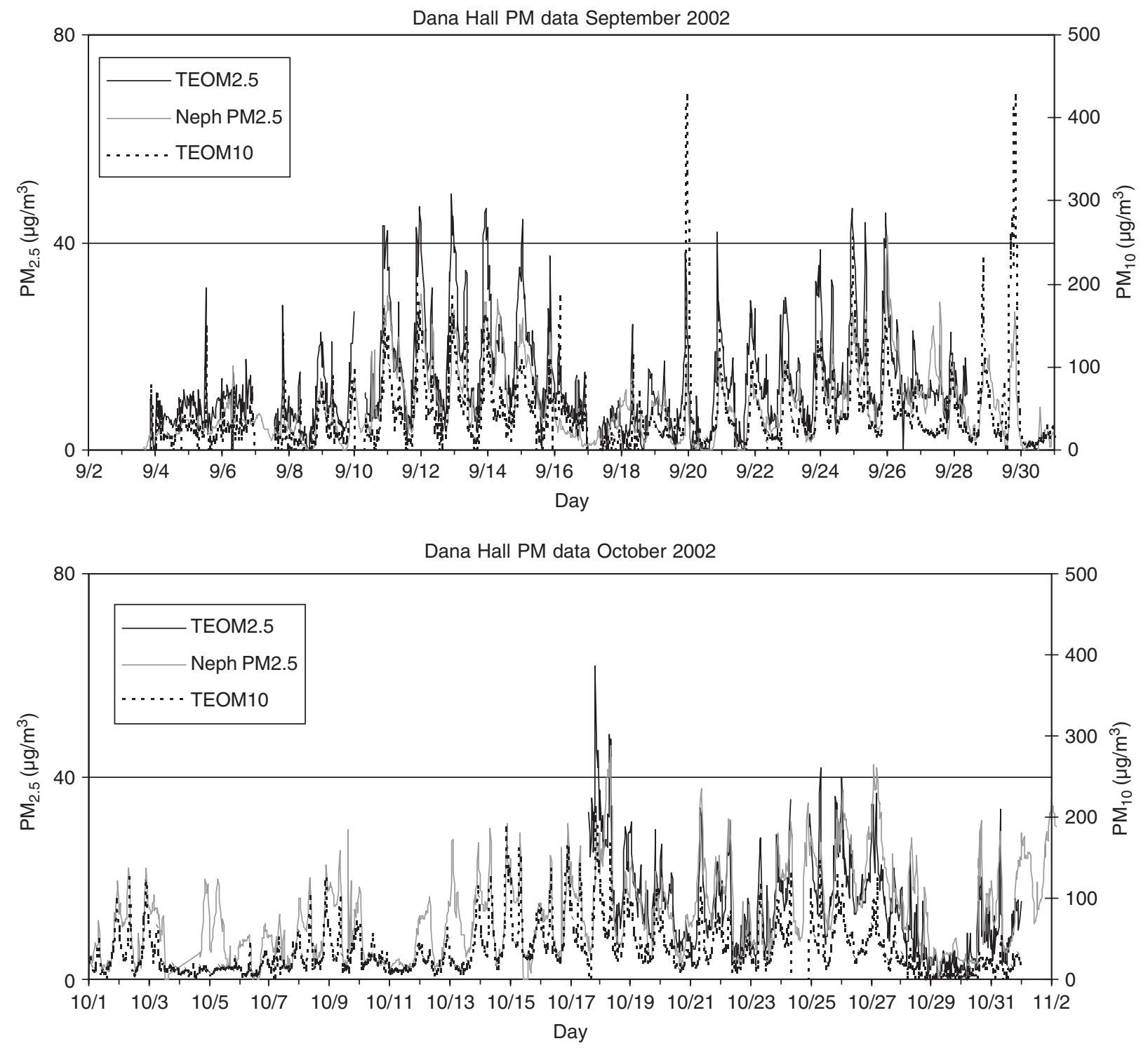

Fig. 1. Continuous 30-min average $\mathrm{PM}_{2.5}$ and $\mathrm{PM}_{10}$ concentrations measured by TEOM and nephelometer during the study. 
Table 2

Summary of statistics for PM and gaseous pollutant observations at the central site during the 2-month study period

\begin{tabular}{|c|c|c|c|c|c|c|}
\hline Parameter & $\begin{array}{l}\text { TEOM }_{10} \\
\left(\mu \mathrm{g} \mathrm{m}^{-3}\right)\end{array}$ & $\begin{array}{l}\operatorname{TEOM}_{2.5} \\
\left(\mu \mathrm{g} \mathrm{m}^{-3}\right)\end{array}$ & $\begin{array}{l}\text { Neph } \mathrm{PM}_{2.5} \\
\left(\mu \mathrm{g} \mathrm{m}^{-3}\right)\end{array}$ & $\mathrm{CO}(\mathrm{ppm})$ & $\mathrm{NO}_{x}(\mathrm{ppb})$ & $\mathrm{CO}_{2}(\mathrm{ppm})$ \\
\hline Mean & 40.5 & 13.6 & 11.3 & 0.51 & 34.9 & 465 \\
\hline Standard deviation & 38.8 & 9.4 & 8.0 & 0.56 & 38.1 & 29 \\
\hline 25 Percentile & 16.2 & 6.8 & 4.9 & 0.09 & 9.8 & 438 \\
\hline Median & 28.6 & 11.4 & 9.3 & 0.32 & 20.1 & 464 \\
\hline 75 percentile & 51.9 & 17.8 & 15.9 & 0.71 & 45.5 & 483 \\
\hline Observations $(N)$ & 2684 & 1872 & 2788 & 784 & 2857 & 2841 \\
\hline Frequency $\mathrm{PM}_{2.5}>40 \mu \mathrm{g} \mathrm{m}^{-3}$ & - & 38 & 9 & - & - & - \\
\hline
\end{tabular}

30-min average integration time.

Table 3

Summary of statistics for the 12-h integrated PM samples at the central site during the 2-month study period

\begin{tabular}{|c|c|c|c|c|c|c|c|c|c|c|}
\hline \multirow[t]{2}{*}{ Species } & \multicolumn{5}{|l|}{ Day } & \multicolumn{5}{|l|}{ Night } \\
\hline & Mean & Median & Min & Max & $N$ & Mean & Median & Min & Max & $N$ \\
\hline${ }^{1} \mathrm{HI}_{2.5}^{+}{ }^{+}$ & 10.0 & 9.6 & 2.9 & 21.9 & 58 & 13.0 & 11.3 & 2.1 & 31.0 & 59 \\
\hline${ }^{1} \mathrm{OC}$ & 3.8 & 3.6 & 1.1 & 7.1 & 56 & 3.9 & 3.77 & 1.0 & 7.8 & 57 \\
\hline${ }^{1} \mathrm{EC}$ & 0.4 & 0.2 & 0.0 & 3.3 & 56 & 0.5 & 0.4 & 0.0 & 1.9 & 57 \\
\hline${ }^{2} \mathrm{LG}^{++}$ & 50 & 31 & 2 & 327 & 45 & 96 & 76 & 3 & 318 & 50 \\
\hline${ }^{2} \mathrm{Si}^{++}$ & 413 & 361 & 20 & 2088 & 60 & 996 & 967 & 13 & 2721 & 63 \\
\hline${ }^{2} \mathrm{Al}^{++}$ & 137 & 121 & 0 & 692 & 60 & 363 & 313 & 0 & 958 & 63 \\
\hline${ }^{2} \mathrm{~S}^{++}$ & 252 & 252 & 68 & 675 & 60 & 206 & 177 & 62 & 416 & 63 \\
\hline${ }^{2} \mathrm{Ca}^{++}$ & 77 & 71 & 4 & 333 & 60 & 210 & 148 & 0 & 533 & 63 \\
\hline${ }^{2} \mathbf{K}^{++}$ & 83 & 71 & 19 & 254 & 60 & 121 & 118 & 13 & 287 & 63 \\
\hline${ }^{2} \mathrm{Na}$ & 46 & 30 & 0 & 315 & 60 & 52 & 20 & 0 & 272 & 63 \\
\hline${ }^{2} \mathrm{Mg}^{++}$ & 12 & 3 & 0 & 87 & 60 & 38 & 19 & 0 & 186 & 63 \\
\hline${ }^{2} \mathrm{Ba}$ & 6 & 0 & 0 & 44 & 60 & 8 & 0 & 0 & 64 & 63 \\
\hline${ }^{2} \mathrm{Zn}^{+}$ & 6 & 4 & 0 & 28 & 60 & 8 & 6 & 0 & 31 & 63 \\
\hline${ }^{2} \mathrm{Cl}$ & 6 & 2 & 0 & 72 & 60 & 7 & 4 & 0 & 45 & 63 \\
\hline
\end{tabular}

${ }^{1}$ Units of mass concentration in $\mu \mathrm{g} \mathrm{m}^{-3}$.

${ }^{2}$ Units of mass concentration in $\mathrm{ng} \mathrm{m}^{-3}$.

${ }^{+} p<0.05 ;{ }^{+} p<0.01$.

respectively, with TEOM $_{2.5}$ exceeding $40 \mu \mathrm{g} \mathrm{m}^{-3}$ for 38 30-min periods, while the nephelometer recorded 930 -min periods exceeding $40 \mu \mathrm{g} \mathrm{m}^{-3}$. The discrepancy in peak values between $\mathrm{TEOM}_{2.5}$ and nephelometer is discussed later. Note that there were only four exceedances recorded by the nephelometer located near downtown Pullman (Table 1). The difference in the number of exceedances between the downtown and WSU sites could be due partially to the spatial variation. The DOE site was located in a residential area $(\sim 1 \mathrm{~km}$ away from the WSU site) with less vehicular traffic and facing a different direction relative to our central site. The DOE site was also slightly higher than the WSU site, which may result in lower concentrations (Wu et al., 2004).

Table 3 summarizes the 12 -h integrated $\mathrm{PM}_{2.5}$, OC, EC, LG, and trace element concentrations. The mean nighttime values were higher than the daytime values for $\mathrm{PM}_{2.5}(p<0.01), \mathrm{LG}(p<0.01)$ and for $\mathrm{Si}$, $\mathrm{Al}, \mathrm{S}, \mathrm{Ca}, \mathrm{K}$ and $\mathrm{Mg}(p<0.01)$. These differences could be due to the effect of nighttime inversions with limited vertical mixing and/or nighttime residential wood burning. However, based on the 2000 census data, there were only $30(0.3 \%)$ homes in Pullman using wood as heating source. The regression analysis between RCFM and $\mathrm{HI}_{2.5}$ (intercept $=0.31, \quad$ slope $=0.93, \quad R^{2}=0.89$, 
$N=123$ ) showed a good consistency between the reconstructed $\mathrm{PM}_{2.5}$ and the actual gravimetric $\mathrm{PM}_{2.5}$ mass concentrations. Our LG measurements $\left(\right.$ mean $=74 \mathrm{ng} \mathrm{m}^{-3}$, range $2-327 \mathrm{ng} \mathrm{m}^{-3}$ ) were comparable to measurements obtained in Israel, mean $\sim 73 \mathrm{ng} \mathrm{m}^{-3}$ (Graham et al., 2004) and higher than those observed in Brazil during rice and sugar cane crop burning, 1.65-7.45 $\mathrm{ng} \mathrm{m}^{-3}$ (Santos et al., 2004) and $0.15-28.42 \mathrm{ng} \mathrm{m}^{-3}$ (Santos et al., 2002), and Nigeria, $0.04-3.3 \mathrm{ng} \mathrm{m}^{-3}$ (Stanley and Simoneit, 1990; Simoneit et al., 1988). However, our observations were lower than those detected in US urban areas, 280-4860 $\mathrm{ng} \mathrm{m}^{-3}$ and 200-1200 $\mathrm{ng} \mathrm{m}^{-3}$ (Simoneit et al., 1993, 1999; Nolte et al., 2002; Fraser and Lakshmanan, 2000), and far below those observed during severe episodes of biomass smoke pollution from agricultural slash and burning in Southeast Asia, $1400-40,240 \mathrm{ng} \mathrm{m}^{-3}$ (Radzi Bin Abas et al., 2004). To date, there have not been specifically reported LG levels from wheat stubble burning. Thus, the differences between our observed LG levels and others could also be due to the type of wood/crops burned.

The correlations between air pollutants are summarized in Table 4. The Pearson's correlation coefficients, which were consistent with the Spearman's coefficients were high for the $\mathrm{TEOM}_{10}$ and $\mathrm{TEOM}_{2.5}(r=0.84), \mathrm{TEOM}_{2.5}$ and $\mathrm{HI}_{2.5}(r=0.82)$, and Neph and $\mathrm{HI}_{2.5}(r=0.81)$. The lower Pearson's correlation between the 30-min average Neph and TEOM $_{2.5}(r=0.71)$ was due to the observed low concentrations, shorter averaging time, and the fact that the aerosol characteristics and the particle scattering efficiency could differ during these episodes (Liu et al., 2002). The differences found between the $\mathrm{TEOM}_{2.5}$ and $\mathrm{HI}_{2.5}$ mass concentration could be due to the higher uncertainties at low $\mathrm{PM}_{2.5}$ concentrations and a possible overestimation on TEOM $_{2.5}$ equipped with a URG cyclone (Moore and McFarland, 1993). During a performance study under different loading conditions, it was reported that the URG type cyclone had a very shallow particle size selection curve and was likely to overestimate $\mathrm{PM}_{2.5}$ concentrations when sampling coarse aerosols (Kenny, 1998). With a significant contribution of dust aerosols in our study area, this inlet artifact may partially account for the difference found between the TEOM ${ }_{2.5}$ and the $\mathrm{HI}_{2.5}$.

$\mathrm{NO}_{x}, \mathrm{OC}$ and $\mathrm{LG}$ were also correlated with $\mathrm{HI}_{2.5}$ $(r>0.47, p<0.01)$, suggesting that some of the $\mathrm{PM}_{2.5}$ was related to vegetative combustion sources. Concentrations of $\mathrm{EC}$ and $\mathrm{CO}_{2}$ during episodes

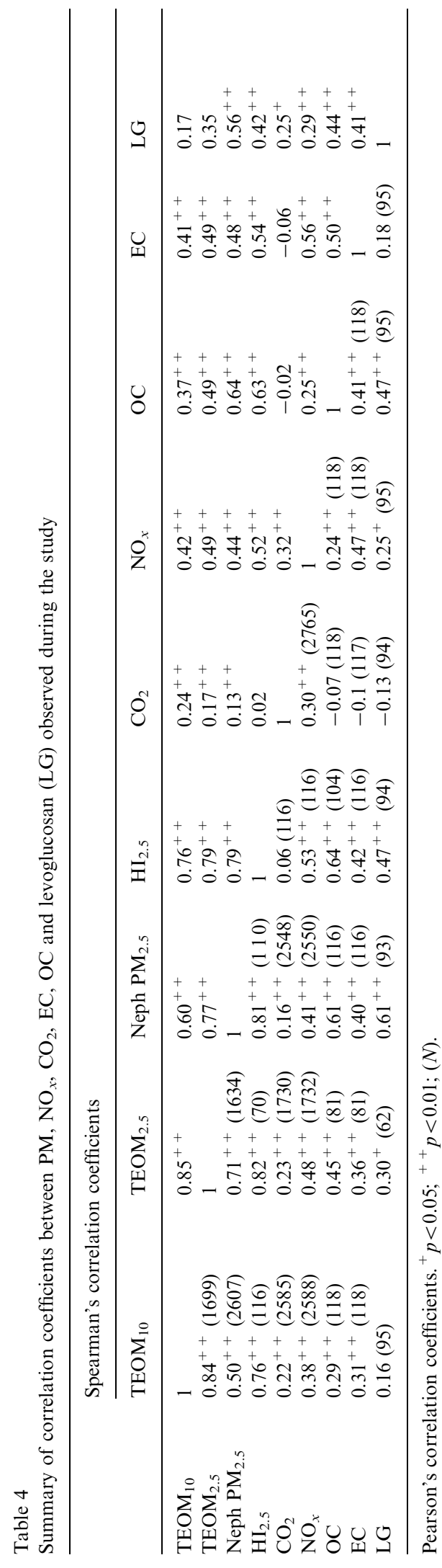


were not different from those during non-episode periods and also showed the least correlations with other parameters. We did not find a strong correlation $(r=0.27, p<0.05)$ between humidity and PM, nor for wind speed and apportioned airborne dust $(r=-0.37, p<0.05)$. We had expected contribution of airborne dust from adjacent fields and from roads (vehicular traffic) at low relative humidity and high wind speed under the right wind direction. This negative correlation between wind speed and airborne dust showed that not necessarily all observed dust was suspended in the air due to the effect of wind.

\subsection{Source apportionment}

\subsection{1. $C M B$ model}

Fig. 2 shows the chemical profiles for the five sources used in the CMB model. LG was used as a unique tracer for vegetative burning smoke to allow for a better separation from other combustion sources. The average $\mathrm{PM}_{2.5}$ contribution from airborne soil was $4.6 \mu \mathrm{g} \mathrm{m}^{-3}(38 \%)$; from vegetative burning $4.0 \mathrm{\mu g} \mathrm{m}^{-3}(35 \%)$; from sulfate aerosol $2.2 \mu \mathrm{g} \mathrm{m}^{-3}(20 \%)$; from vehicular traffic $0.2 \mu \mathrm{g} \mathrm{m}^{-3}$ $(2 \%)$; from cooking $0.1 \mu \mathrm{g} \mathrm{m}^{-3}(1 \%)$; and $0.4 \mu \mathrm{g} \mathrm{m}^{-3}$ $(4 \%)$ from unexplained sources. Table 5 summarizes

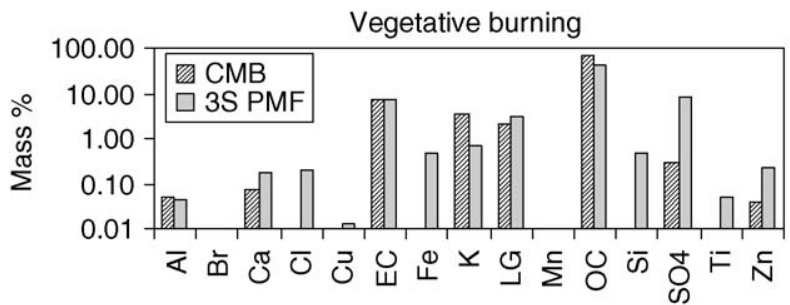

Tracer

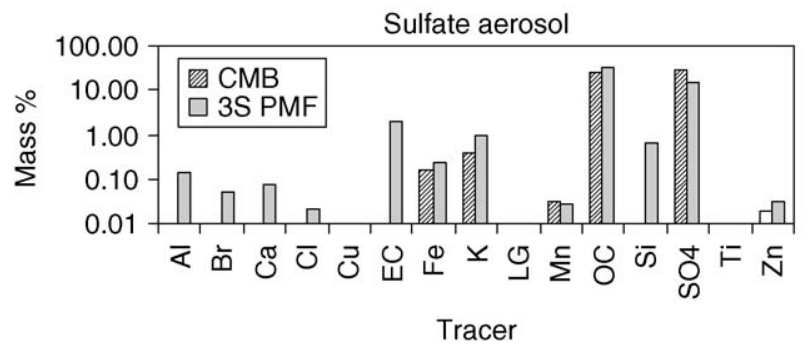

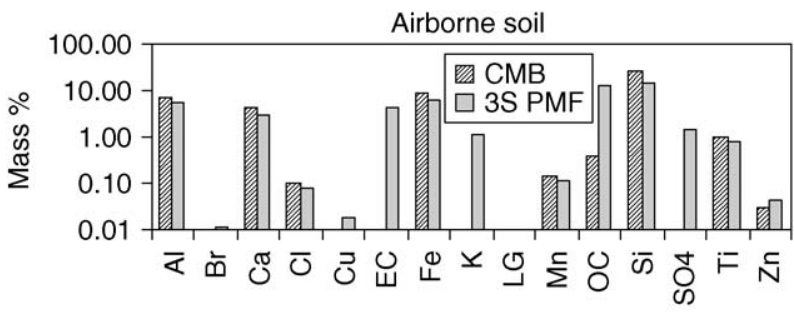

Tracer

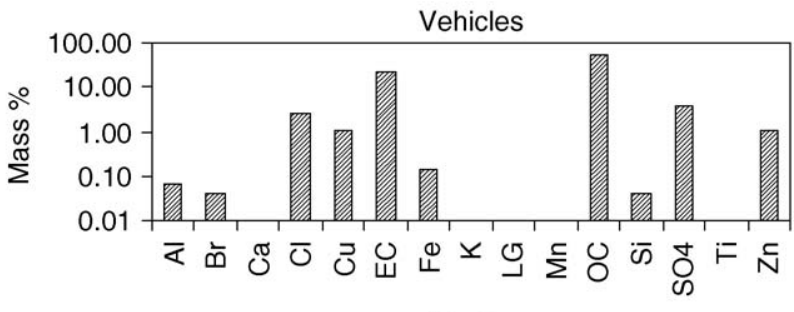

Tracer

Fig. 2. Source profiles selected for CMB and predicted by $3 \mathrm{~s}$ PMF analysis for the samples collected at the central site in Pullman during the 2 months study.

Table 5

Summary of average source contributions to fine particle mass concentration found in Spokane and Pullman

\begin{tabular}{|c|c|c|c|c|c|c|c|}
\hline \multicolumn{3}{|c|}{ Average source contribution in Spokane ${ }^{\mathrm{a}}$ Kim et al. (2003) } & \multicolumn{5}{|c|}{ Average source contribution in Pullman } \\
\hline \multirow[t]{2}{*}{ Mass contribution } & \multicolumn{2}{|l|}{ PMF } & \multirow[t]{2}{*}{ Mass contribution } & \multicolumn{2}{|l|}{$\mathrm{CMB}$} & \multicolumn{2}{|l|}{${ }^{\mathrm{b}} \mathrm{PMF}$} \\
\hline & $\left(\mu \mathrm{g} \mathrm{m}^{-3}\right)$ & $\%$ & & $\left(\mu \mathrm{g} \mathrm{m}^{-3}\right)$ & $\%$ & $\left(\mu \mathrm{g} \mathrm{m}^{-3}\right)$ & $\%$ \\
\hline Vegetative burning & $5.28 \pm 0.14$ & 44 & Vegetative burning & $3.96 \pm 0.13$ & 35 & $1.81 \pm 1.57$ & 17 \\
\hline Airborne soil & $1.01 \pm 0.04$ & 8 & Airborne soil & $4.55 \pm 0.03$ & 38 & $6.20 \pm 5.22$ & 57 \\
\hline Sulfate aerosol & $2.30 \pm 0.04$ & 19 & Sulfate aerosol & $2.22 \pm 0.06$ & 20 & $2.82 \pm 2.14$ & 26 \\
\hline Motor vehicle & $1.29 \pm 0.04$ & 11 & Motor vehicle & $0.19 \pm 0.01$ & 2 & - & 一 \\
\hline Nitrate aerosol & $1.04 \pm 0.05$ & 9 & Cooking & $0.12 \pm 0.04$ & 1 & - & 一 \\
\hline Chlorine-rich & $0.68 \pm 0.03$ & 6 & Unexplained & $0.42 \pm 0.24$ & 4 & - & - \\
\hline Metal processing & $0.29 \pm 0.01$ & 3 & & & & & \\
\hline
\end{tabular}

\footnotetext{
${ }^{\text {a}}$ The Spokane study was conducted from 1995 through 1997, and PMF was used for source apportionment.

${ }^{\mathrm{b}} \mathrm{PMF}$ estimates and standard deviation, $(N=123)$.
} 
the average source contributions to fine aerosol mass concentrations in this study and compares our results with those from a source apportionment study in Spokane (Kim et al., 2003), which is a larger city approximately $120 \mathrm{~km}$ north of Pullman. The average $\mathrm{CMB}$ vegetative burning $\mathrm{PM}_{2.5}$ was slightly higher in Spokane than Pullman. However, the average airborne soil $\mathrm{PM}_{2.5}$ observed in Pullman was four times larger than that in Spokane. This is probably due to the numerous unpaved roads surrounding Pullman. In addition, the contribution of $\mathrm{PM}_{2.5}$ from vehicles was greater in Spokane than in Pullman, which is consistent with the greater amount of vehicular traffic in Spokane. The average contribution of sulfate aerosol to $\mathrm{PM}_{2.5}$ was similar in both cites, suggesting a regional source of sulfate aerosol. During the study we found a significant inverse correlation $(r=-0.6, p<0.01)$ between LG and ambient temperature, which could be due to limited atmospheric mixing or more frequent residential wood burning at lower temperatures. Note that we could not distinguish LG emitted from residential wood burning from that emitted by agricultural burning.

\subsubsection{PMF modeling results}

The 3-source PMF model identified vegetative burning, windblown dust, and secondary sulfate sources, with similar source profiles (shown as grey bars in Fig. 2) to those used in the CMB analysis. This suggests that the CMB source profiles, which were compiled from studies in nearby cities, were suitable for the Pullman airshed. Note that LG was a significant component in only one profile (vegetative burning) in the PMF modeling results, supporting the use of $\mathrm{LG}$ as a unique tracer for vegetative burning. The source-specific $\mathrm{PM}_{2.5}$ mass concentrations estimated from the two models (PMF and CMB) were highly correlated $(p<0.01)$, with a Pearson's correlation coefficient of $0.70,1.00$ and 0.88 for vegetative burning, windblown dust, and secondary sulfate contributions respectively (Fig. 3). However, when compared to CMB estimates, the PMF apportioned $\mathrm{PM}_{2.5}$ mass concentrations were consistently lower $(\sim 46 \%$ lower $)$ for vegetative burning and higher for airborne soil ( $\sim 40 \%$ higher) and sulfate aerosol ( $\sim 70 \%$ higher). This discrepancy could be explained by the slight differences in the relative proportion of tracers in source profiles resulting from literature values (CMB) and statistics (PMF). For further analysis, we chose the CMB estimates over the 3 -source PMF
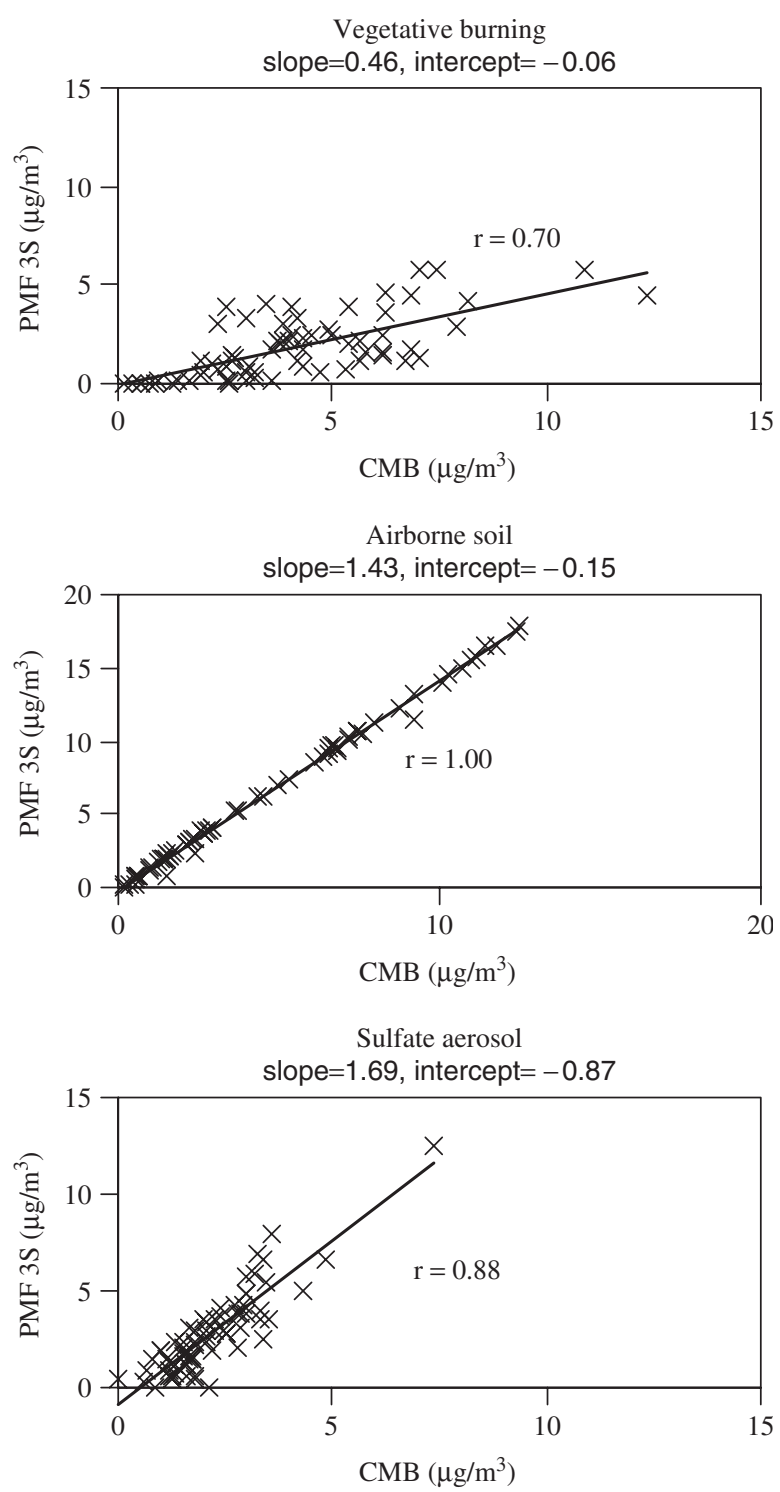

Fig. 3. Correlation between CMB and PMF 3S apportionment for the major sources of fine PM in Pullman.

results due to the sample size constraints for PMF (relatively small size $N=123$ ) (Henry, 2002). Ultimately, the PMF results served as an independent method to further confirm the CMB results through the similarity of source profiles, identification of $\mathrm{LG}$ as a unique tracer for biomass burning, and high correlations of source estimates between the two methods.

\subsection{Episode calls}

Table 6 compares pollutant concentrations during episodes $\left(16.8 \pm 8.6 \mu \mathrm{g} \mathrm{m}^{-3}\right)$ vs. non-episode 
Table 6

Summary of results comparing $\left(t\right.$-test $\left.{ }^{*}\right)$ air pollution measurements and estimates between real episode (regardless of declaration) and nonepisode (including sham) days

\begin{tabular}{lcc}
\hline Variable & All episodes ${ }^{* *}$ Mean $\pm \mathrm{SD}(N)$ & Non episodes $^{* *}$ Mean $\pm \mathrm{SD}(N)$ \\
\hline $\mathrm{Neph} \mathrm{PM}_{2.5}\left(\mu \mathrm{g} \mathrm{m}^{-3}\right)$ & $16.76 \pm 8.63(1442)$ & $10.30 \pm 8.79(7119)$ \\
$\mathrm{LG}\left(\mathrm{ng} \mathrm{m}^{-3}\right)$ & $106 \pm 115(19)$ & $59 \pm 70(86)$ \\
$\mathrm{NO}_{x}(\mathrm{ppb})$ & $42.33 \pm 43.31(461)$ & $33.94 \pm 37.01(2370)$ \\
$\mathrm{CO}_{2}(\mathrm{ppm})$ & $470 \pm 36(483)$ & $463 \pm 30(2362)$ \\
$\mathrm{OC}\left(\mu \mathrm{g} \mathrm{m}^{-3}\right)$ & $4.75 \pm 1.94^{++}(24)$ & $3.14 \pm 1.48(94)$ \\
$\mathrm{EC}\left(\mu \mathrm{g} \mathrm{m}^{-3}\right)$ & $0.59 \pm 0.53^{++}(24)$ & $0.41 \pm 0.53(94)$ \\
Vegetative burning $\left(\mu \mathrm{g} \mathrm{m}^{-3}\right)$ & $5.22 \pm 2.96^{++}(19)$ & $2.97 \pm 1.80(78)$ \\
Airborne soil $\left(\mu \mathrm{g} \mathrm{m}^{-3}\right)$ & $6.92 \pm 3.86(19)$ & $2.83 \pm 2.73(78)$ \\
Sulfate $\left(\mu \mathrm{g} \mathrm{m}^{-3}\right)$ & $2.41 \pm 0.75^{++}(19)$ & $2.21 \pm 1.13(78)$ \\
Vehicles $\left(\mu \mathrm{g} \mathrm{m}^{-3}\right)$ & $0.22 \pm 0.19^{++}(19)$ & $0.15 \pm 0.17(78)$ \\
Cooking $\left(\mu \mathrm{g} \mathrm{m}^{-3}\right)$ & $0.09 \pm 0.19(19)$ & $0.11 \pm 0.29(78)$ \\
\hline
\end{tabular}

${ }^{*} t$-Test applied to normal or log-normal distributed data. ${ }^{* *}$ Original data. ${ }^{+} p<0.05 ;{ }^{++} p<0.01$.

days $\left(10.5 \pm 8.5 \mu \mathrm{g} \mathrm{m}^{-3}\right)$, including the sham episode $\left(4.9 \pm 4.0 \mu \mathrm{g} \mathrm{m}^{-3}\right)$. By definition, the continuous PM observations from the nephelometer were higher during all episodes than those during non-episode days. $\mathrm{LG}, \mathrm{NO}_{x}, \mathrm{CO}_{2}$ and $\mathrm{OC}$ were also higher during episode than non-episode days, with or without controlling for temperature using ANOVA. The CMB-estimated source contributions for episode vs. non-episode days are also shown in Table 6. PM from vegetative burning was significantly higher during episode days $\left(5.2 \mu \mathrm{g} \mathrm{m}^{-3}\right)$ than non-episode days $\left(3.0 \mu \mathrm{g} \mathrm{m}^{-3}\right)$. However, we found a larger contribution of $\mathrm{PM}_{2.5}$ from soil during episode $\left(6.9 \mu \mathrm{g} \mathrm{m}^{-3}\right)$ than non-episode days $\left(2.8 \mu \mathrm{g} \mathrm{m}^{-3}\right)$. As expected, PM from other sources (secondary sulfate, vehicle, and cooking) did not differ between episodes and non-episode days.

This study was conducted during the fall dry season, which also experienced enhanced dust intrusion from nearby roads and adjacent fields upwind of Pullman. Thus, it was likely that the realtime $\mathrm{PM}_{2.5}$ measurements were enhanced by both the presence of airborne soil dust and vegetative burning smoke. Although if an episode declaration was based solely on the criterion of exceeding a threshold $\mathrm{PM}_{2.5}$ value of $40 \mu \mathrm{g} \mathrm{m}^{-3}$, the mass measurements alone could not distinguish the soil from the biomass burning contribution. We also analyzed the effects of burn calls and total acreage burned during episode vs. non-episode days. These attempts failed because of the difficulties in collecting burn calls in the region across two states and inaccurate records of acreages burned. We also conducted back trajectory analyses to track movement of the air mass during episodes but encoun- tered similar difficulties in locating the exact field burn sites on any specific day.

\section{Conclusions}

This study characterized the air quality in Pullman, WA during the 2002 fall burning season. We found that the average $\mathrm{PM}_{2.5}$, OC and $\mathrm{EC}$ concentrations in Pullman were very similar during the daytime and nighttime, while LG was significantly higher during the nighttime due to trapping inversions and/or possibly residential wood burning. Good correlations between $\mathrm{PM}_{2.5}$ and $\mathrm{NO}_{x}$ as well as with $\mathrm{OC}, \mathrm{LG}$ and $\mathrm{HI}_{2.5}$ suggested that some of the observed $\mathrm{PM}_{2.5}$ originated from combustion sources upwind of the monitoring site.

Vegetative burning was found to be the second largest source of $\mathrm{PM}_{2.5}(35 \%)$, after airborne soil $(38 \%)$. Our CMB results were consistent with those found previously in Spokane, WA. In addition, the a priori $\mathrm{CMB}$ source profiles were similar to those identified by the PMF algorithm. Furthermore, the source-specific $\mathrm{PM}_{2.5}$ mass concentrations estimated by $\mathrm{CMB}$ were highly correlated with the contributions from the subset of sources identified by PMF. The PMF results confirmed that the CMB source profiles compiled from studies in other nearby cities were applicable to the Pullman airshed.

In this study, four smoke episodes were identified. $\mathrm{LG}, \mathrm{NO}_{x}, \mathrm{CO}_{2}, \mathrm{OC}$, and apportioned biomass burning $\mathrm{PM}_{2.5}$ were higher during episode compared to non-episode days. EC was not considerably elevated during the episode periods. On the other hand, airborne dust also showed elevated levels during the defined field burning episodes. $\mathbf{P M}_{2.5}$ 
measurements alone could not be used to distinguish biomass combustion contribution from soil contribution during these episodes because the study was conducted in the dry season with soil enhancement.

\section{Acknowledgements}

We thank the subjects and Collen Marquist, Kristen Shepherd, Lianne Sheppard, Ranil Dhammapala, Mark Hoffman, Dennis Finn, Lee Bamesberger, Kristie Schumaker, and Sara Jarvis who devoted much of their time to our agricultural burning air and health monitoring work. We thank Mr. Grant Pfeifer and Ms. Karen Wood of the Washington Department of Ecology for their support and assistance in study design. We appreciate comments provided by the Washington Expert Panel. This study was funded by WA Department of Ecology Interagency Agreement C03000099 and the EPA Northwest Center for Particulate Air Pollution and Health grant R827355.

\section{References}

Allen, R., Box, M., Liu, S., Larson, T., 2001. A cost-effective weighing chamber for particulate matter filters. J. Air Waste Manage. Assoc. 51, 1650-1653.

Box, G., Cox, D., 1964. An analysis of transformations. Journal of the Royal Statistical Society, 211-243.

Cass, G.R., McRae, G. 1981. Source-Receptor Reconciliation of South Coast Air Basin Particulate Air Quality Data-Draft. Prepared for California Air Resources Board.

Claiborn, C., Finn, D., Larson, T., Koenig, J., 2000. Windblown dust contributes to high PM concentrations. Journal of the Air and Waste Management Association 50, 1440-1445.

Core, J., et al., 1982. A Study of Residential Wood Combustion Task 1-Ambient Air Quality Impact Analysis. Report Prepared for US Environmental Protection Agency, EPA Region $\mathrm{X}$ by NEA, Inc.

Delfino, R.J., Zeiger, R.S., Seltzer, J.M., Street, D.H., McLaren, C.E., 2002. Association of asthma symptoms with peak particulate air pollution and effect modification by antiinflammatory medication use. Environmental Health Perspectives 110 (10), A607-A617.

Delfino, R.J., Gong, H., Linn, W.S., Pellizzari, E.D., Hu, Y., 2003. Asthma symptoms in Hispanic children and daily ambient exposures to toxic and criteria air pollutants. Environmental Health Perspectives 111 (4), 647-656.

Fraser, M., Lakshmanan, K., 2000. Using levoglucosan as a molecular marker for the long-range transport of biomass combustion aerosols. Environmental Science and Technology 34 (21), 4560-4564.

Graham, B., Falkovich, A., Rudich, Y., Maenhaut, W., Guyon, P., Andreae, M., 2004. Local and regional contributions to the atmospheric aerosol over Tel Aviv, Israel: a case study using elemental, ionic and organic tracers. Atmospheric Environment 38, 1593-1604.

Henry, R., 2002. Multivariate receptor models - current practices and future trends. Chemometrics and Intelligent Laboratory Systems 60, 43-48.

Hildemann, L., Markowski, G., Cass, G., 1991. Chemical composition of emissions from urban sources of fine organic aerosol. Environmental Science \& Technology 25 (4), 744-754.

Hoffman, M., 2002. Elemental analysis and receptor modeling of airborne particulate matter in Spokane, Washington. WSU Master thesis.

Jenkins, B., Jones, D., Turn, S., Williams, R., 1996. Emission factors for polycyclic hydrocarbons from biomass burning. Environmental Science \& Technology 30 (8), 2462-2469.

Jimenez, J., 2002. Air quality impact from agricultural field burning in Pullman. Master Thesis. Washington State University.

Kenny, L., 1998. Investigation of the effects of loading on $\mathrm{PM}_{2.5}$ selectors. Health and safety laboratory: IR/L/A/98/13

Kim, E., Larson, T.V., Hopke, P.K., Slaughter, C., Sheppard, L.E., Claiborn, C., 2003. Source identification of $\mathrm{PM}_{2.5}$ in an arid Northwest US City by positive matrix factorization. Atmospheric Research 66 (4), 291-305.

Liu, L.J.S., Slaughter, J.C., Larson, T.V., 2002. Comparison of light scattering devices and impactors for particulate measurements in indoor, outdoor, and personal environments. Environmental Science \& Technology 36 (13), 2977-2986.

Liu, L.-J.S., Box, M., Kalman, D., Kaufman, J., Koenig, J., Larson, T., Lumley, T., Sheppard, L., Wallace, L., 2003. Exposure assessment of particulate matter for susceptible populations in Seattle, WA. Environmental Health Prospectives 111 (7), 909-918.

Long, W., Tate, R., Neuman, M., Manfreda, J., Becker, A., Anthonisen, N., 1998. Respiratory symptoms in a susceptible population due to burning of agricultural residue. Chest 113 (2), 351-356.

Malm, W., Sisler, J., Huffman, D., Eldred, R., Cahill, T., 1994. Spatial and seasonal trends in particle concentration and optical extinction in the United States. Journal of Geophysical Research 99, 1347-1370.

Maykut, N., Lewtas, J., Kim, E., Larson, T., 2003. Source apportionment of $\mathrm{PM}_{2.5}$ at an urban IMPROVE site in Seattle, Washington. Environmental Science \& Technology 37 (22), 5135-5142.

Moore, M., McFarland, A., 1993. Performance modeling of single-inlet aerosol sampling cyclones. Environmental Science \& Technology 27 (9), 1842-1848.

Nolte, C., Schauer, J., Cass, F., Simoneit, B., 2002. Trimethyl derivatives of organic compounds in source samples and in atmospheric fine particulate matter. Environmental Science \& Technology 36, 4273-4281.

Oros, D., Simoneit, B., 2001a. Identification and emission factors of molecular tracer in organic aerosols from biomass burning: Part 1. Temperate climate conifers. Applied Geochemistry 16 (13), 1513-1544.

Oros, D., Simoneit, B., 2001b. Identification and emission factors of molecular tracers in organic aerosol from biomass burning. Part 2. Deciduous tress. Applied Geochemistry, $1545-1565$.

Ostro, B., Lipsett, M., Mann, J., Braxton-Owens, H., White, M., 2001. Air pollution and exacerbation of asthma in 
African-American children in Los Angeles. Epidemiology 12 (2), 200-208.

Paatero, P., 1997. Least squares formulation of robust nonnegative factor analysis. Chemometrics and Intelligent Laboratory Systems 37 (1), 23-35.

Pang, Y., Gundel, L., Larson, T., Finn, D., Liu, L-J.S., Claiborn, C., 2002. Development and evaluation of a novel Personal Particulate Organic Mass Sampler (PPOMS). Environmental Science \& Technology 36 (23), 5205-5210.

Pekkanen, J., Timonen, K.L., Ruuskanen, J., Reponen, A., Mirme, A., 1997. Effects of ultrafine and fine particles in urban air on peak expiratory flow among children with asthmatic symptoms. Environmental Research 74 (1), 24-33.

Peters, A., Dockery, D.W., Heinrich, J., Wichmann, H.E., 1997. Short-term effects of particulate air pollution on respiratory morbidity in asthmatic children. European Respiratory Journal 10 (4), 872-879.

Polissar, A.V., Hopke, P.K., Poirot, R.L., 2001. Atmospheric aerosol over Vermont: Chemical composition and sources. Environmental Science \& Technology 35 (23), 4604-4621.

Radzi Bin Abas, M., Noorsaadah, A., Nasr Yousef, M., Jamil Maah, M., Azian Abu, S., Oros, D., Otto, A., Simoneit, B., 2004. Organic composition of aerosol particulate matter during a haze episode in Kuala Lampur, Malaysia. Atmospheric Environment 38, 4223-4241.

Roberts, R., Corkill, J., 1998. Grass Seed Field Smoke and Its Impact on Respiratory Health. Environmental Health 60 (10), $10-15$.

Roemer, W., Hoek, G., Brunekreef, B., 2000. Pollution effects on asthmatic children in Europe, the PEACE study. Clinical and Experimental Allergy 30 (8), 1067-1075.

Romieu, I., Meneses, F., Ruiz, S., Sienra, J.J., Huerta, J., White, M.C., Etzel, R.A., 1996. Effects of air pollution on the respiratory health of asthmatic children living in Mexico City. American Journal of Respiratory and Critical Care Medicine 154 (2), 300-307.

Santos, C., Azevedo, D., Aquino Neto, F., 2002. Selected organic compounds from biomass burning found in the atmospheric particulate matter over sugar cane plantation areas. Atmospheric Environment 36, 3009-3019.

Santos, C., Azevedo, D., Aquino Neto, F., 2004. Atmospheric distribution of organic compounds from urban areas near a coal-fired power station. Atmospheric Environment 38, 1247-1257.

Simoneit, B., Cox, R., Stanley, L., 1988. Organic matter of the troposphere IV. Lipids in Harmattan aerosols of Nigeria. Atmospheric Environment 22, 983-1004.

Simoneit, B., Rogee, W., Mazurek, M., Stanley, L., Cass, G., 1993. Lignin pyrolysis products, lignans, and resin acids as specific tracers of plant classes in emissions from biomass combustion. Environmental Sciences \& Technology 27 (12), 2533-2541.

Simoneit, B., Schauer, J., Nolte, D., Oros, D., Elias, V., Fraser, M., Rogge, W., Cass, G., 1999. Levoglucosan, a tracer for cellulose in biomass burning and atmospheric particles. Atmospheric Environment 33, 173-182.

Simpson, C., Dills, R., Katz, B., Kalman, D., 2004. Determination of levoglucosan in atmospheric fine particulate matter. Journal of the Air and Waste Management Association 54, 689-694.

Stanley, L., Simoneit, B., 1990. Preliminary correlation of organic molecular tracers in residential wood smoke with the source of fuel. Atmospheric Environment 24B, 163-169.

Sullivan, J.H., Shephard, K., Trenga, C.A., Kaufman, J., Wu, C.F., Jimenez, J., Claiborn, C., Liu, L.-J.S., 2005. The Effects of Agricultural Field Burning on Sub-clinical Measures of Lung Function in Young Adults with Asthma Living in Pullman Washington. Environmental Health Perspectives, submitted for publication.

Sutherland, R., 2004. Outpatient treatment of chronic obstructive pulmonary disease: comparisons with asthma. Journal of Allergy and Clinical Immunology 114, 715-724.

Sutherland, R., Martin, R., 2003. Airway inflammation in chronic obstructive pulmonary disease: comparisons with asthma. Journal of Allergy and Clinical Immunology 112, 819-827.

Tirigoe, K., Satoshi, H., Numata, O., Yazaki, S., Matsunga, M., Boku, N., Hiura, M., Ino, H., 2000. Influence of emission from rice straw burning on bronchial asthma in children. Pediatrics International 42, 143-150.

US EPA-450/4-85-002, Receptor model source composition library. United States Environmental Protection Agency, Office of Air Quality Planning and Standards, Research Triangle Park, NC 27711.

US EPA., 2004. Air quality criteria for particulate matter. EPA/ 600/P-99/022aF and bF. October 2004. US Environmental Protection Agency, Office of Research and Development, National Center for Environmental Assessment, Research Triangle Park Office, Research Triangle Park, NC 27711.

Vedal, S., Petkau, J., White, R., Blair, J., 1998. Acute effects of ambient inhalable particles in asthmatic and nonasthmatic children. American Journal of Respiratory and Critical Care Medicine 157 (4), 1034-1043.

Washington State Department of Ecology, 2004. Alternatives to Agricultural Burning, best management practices to help eliminate or reduce the need to burn. Air Quality Program, Spokane, WA.

Watson, J., Chow, J., Fujita, E., 2001. Review of Volatile Organic Compound source apportionment by chemical mass balance. Atmospheric Environment 35, 1567-1584.

Wu, C.F., Jimenez, J., Claiborn, C.S., Gould, T., Simpson, C.D., Larson, T.V, Liu, L.-J.S., 2005. Agricultural burning smoke in eastern washington: Part II. Exposure assessment. Atmospheric Environment, submitted for publication.

Yu, O.C., Sheppard, L., Lumley, T., Koenig, J.Q., Shapiro, G.G., 2000. Effects of ambient air pollution on symptoms of asthma in Seattle-area children enrolled in the CAMP study. Environmental Health Perspectives 108 (12), 1209-1214. 